\title{
Resource potential and energy efficiency in the buildings of Cameroon: A review
}

\author{
Kameni Nematchoua Modeste ${ }^{\mathrm{a}, *}$, Blaise Mempouo ${ }^{\mathrm{b}}$, Tchinda René ${ }^{\mathrm{c}}$, Ángel M. Costa ${ }^{\mathrm{d}}$, José \\ A. Orosa ${ }^{\mathrm{d}}$, Chrysostôme R.R. Raminosoa ${ }^{\mathrm{e}}$, Ramaroson Mamiharijaona ${ }^{\mathrm{f}}$ \\ a Environmental Energy Technologies Laboratory, University of Yaounde I, Cameroon \\ b Institute of Sustainable Energy Technology, University of Nottingham, Nottingham NG7 2RD, UK \\ ${ }^{c}$ LISIE, University Institute of Technology Fotso Victor, University of Dschang, Cameroon \\ ${ }^{\mathrm{d}}$ Department of Energy and Marine Propulsion,University of A Coruña, Spain \\ e Fluid and Energy Laboratory, University of Antsiranana, Madagascar \\ ${ }^{\mathrm{f}}$ Laboratory of Mechanics and Materials, University of Antsiranana, Madagascar
}

\section{A R T I C L E I N F O}

\section{Article history:}

Received 26 February 2015

Received in revised form

11 May 2015

Accepted 13 May 2015

Available online 2 June 2015

Keywords:

Energy efficiency

Potential resources

Buildings

Codes of Cameroon

Review

\begin{abstract}
A B S T R A C T
Today, more than ever, the human energy requirements are enormous and still growing. Worldwide, all the countries need energy, which is the main source of development. However, the development of African continent is still very slow because of the limited policy interest and investment levels. The effective use of energy is crucial because of the continuous depletion of energy resources, especially for developing countries which are currently experiencing rapid economic and population growth. The aim of this article is to review the status and current trends in resource potential, energy consumption, and energy policies in the residential sector, both globally and in Cameroon. It was found that the world's energy needs are constantly growing and should exceed 50\% of current levels by 2030. In Africa, most of the substantially renewable energy resources are under-exploited. We found that $83 \%$ of the rural population in Africa, 92\% in Sub-Saharan Africa, and 70\% in South Asia have no access to electricity. Especially in Cameroon, the energy consumption in the residential sector is about $70 \%$ of the total energy consumption, which is higher compared to the world level that is around 27\%. Energy efficiency is very important in the context of sustainable development. Currently, traditional biomass is the main source of energy in Sub-Saharan Africa.
\end{abstract}

\section{Contents}

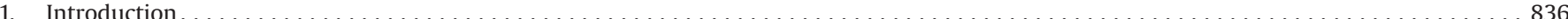

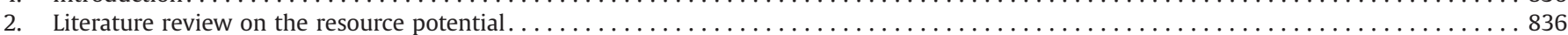

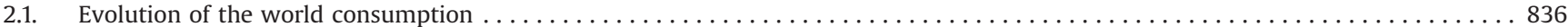

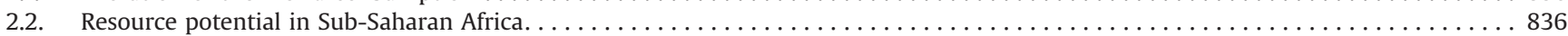

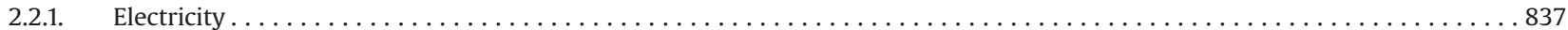

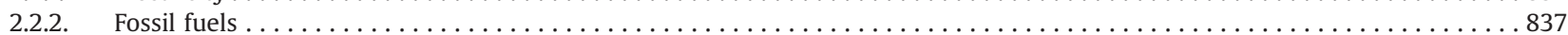

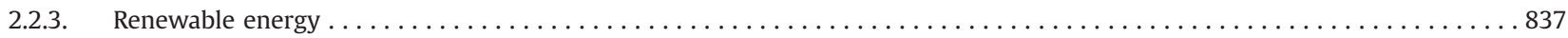

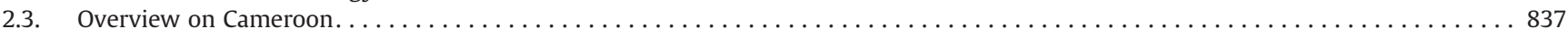

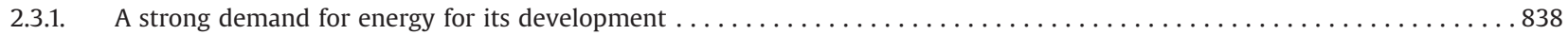

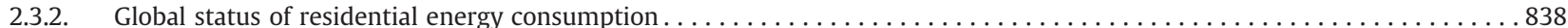

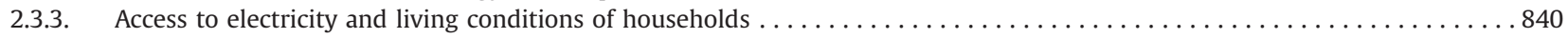

2.3.4. Energy efficiency in the electricity sector in Cameroon. . . . . . . . . . . . . . . . . . . . . . . . . . . . . . 840

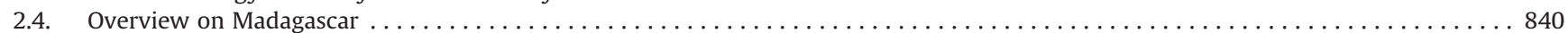

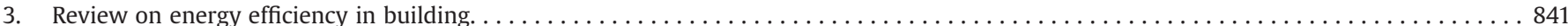

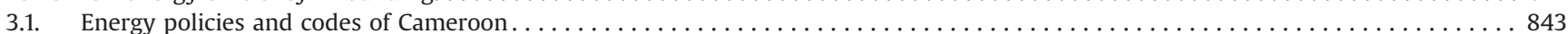

\footnotetext{
* Corresponding author.

E-mail address: kameni.modeste@yahoo.fr (K.N. Modeste).
} 


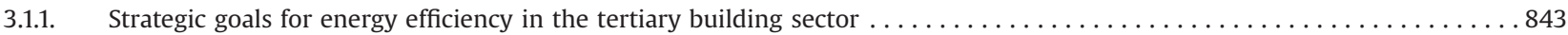

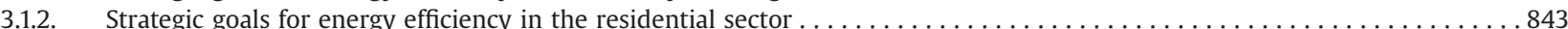

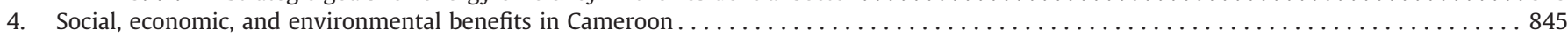

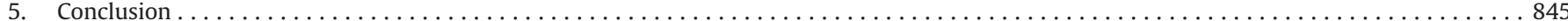

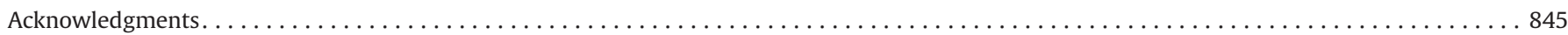

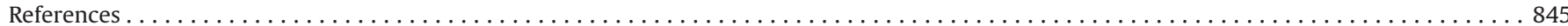

\section{Introduction}

The global economy is functioning based on fossil fuels. Today, $80 \%$ of our needs are met by oil, gas, and coal. World energy consumption is 10 gigatonne of oil equivalent (Gtoe) per year with $1.6 \mathrm{t}$ of oil equivalent (toe) as energy consumption per occupant $[1,2]$. The rapid economic growth in the developing countries has led to an increase in energy consumption and supply difficulties. Hence, the efficient usage of energy is essential in preserving the amount of energy sources available [3]. The energy used by developing nations will exceed the advanced countries by 2020 [4]. Energy is essential for the economic and social development and improved quality of life. Much of the world's energy is currently produced and consumed in ways that could not be sustained and significantly higher than the environmentally friendly renewable energy source. According to The International Energy Agency, during the last two decades (1984-2004) primary energy consumption has grown by $49 \%$ and $\mathrm{CO}_{2}$ emission by $43 \%$ with an average annual increase of $2 \%$ and $1.8 \%$, respectively [5]. However, in Africa, because of the limited policy interests and investment levels, the renewable energy resource potential has not been fully exploited. In addition to this, technical and financial barriers have also contributed to the low levels of incorporation of renewable energy technologies (RET) in Africa [6]. There are, however, prospects for the wide-scale development and dissemination of RETs in the region. Furthermore, there is growing realization that Africa is likely to be disproportionately affected by the impacts of climate change. Of particular concern is the dependence of the poor in Africa on rain-fed agriculture, which is believed to be already under threat from unpredictable weather patterns triggered by the climatic changes. Moreover, the recent floods that adversely affected southern parts of Africa appear to indicate that the impact of climate change may already be a reality. The success of modeling the sustainable performance of the residential building envelope will be to a great extent associated with the sustainable energy performance indicators used, account the targeted objectives [7]. Building Energy Efficiency Retrofit (BEER) encourages implementations of energy sustainability such as environment protection, rational resource use, and occupants' health care and therefore provides excellent opportunities to reduce the energy consumption in buildings [8]. Nowadays developed nations are including a section on energy efficiency within their energy planning policies through implementation of various laws, codes, strategies, regulations, and certification schemes [9]. Since 40 years, the energy demand from buildings has grown by $1.8 \%$ per year which is predicted to grow from 2790 megatonne of oil equivalent (Mtoe) in 2010 to over 4400 Mtoe by 2050 [5]. Building energy standards and strategies are essential because of many invaluable benefits including ensuring energy-efficient design and sustained operations of buildings [10]. In the recast of the European Union's Energy Performance of Buildings Directive (EPBD), it is specified that by the end of 2020, all new buildings shall be "nearly zero energy buildings" [11]. The specific approach of building energy efficiency standards in dealing with energy efficiency may vary between countries. However, building energy efficiency standards generally focus on final energy use for operation by specifying thermal properties and specific final energy use for buildings [12]. Today, China ranks second in the largest building energy usage, ranks first in residential, and ranks third in total commercial energy consumption in the world. However, since 1980, the Chinese government in order to improve building energy efficiency and to reduce total energy demand has developed a variety of building energy codes [13]. Meanwhile, Cameroon at present is recovering gradually from the 1980s' and 90s' severe crisis that had weakened all sectors of economic and social life. The resumption of growth that began in 2006 continued in 2007 and 2008 with an average growth rate of over 3.5\% per year of gross domestic product (GDP). Furthermore, agriculture contributed significantly to the recovery, and to this day, it remains one of the main drivers of growth in Cameroon. Currently, faced with the changing climate and increasing energy demand, Cameroon is speeding up the development of its energy demands using resources such as mineral, water, oil, and gas. However, if appropriate conditions are not deployed, this effort could be destroyed by the extreme weather events. In this regard, this article will make a brief review of the resource potential and energy efficiency in the buildings. We also analyzed the energy consumption in Cameroon and have suggested a code.

\section{Literature review on the resource potential}

\subsection{Evolution of the world consumption}

Globally, about 2.4 billion people use traditional fuels from biomass for cooking and some 1.6 billion do not have access to electricity $[14,15]$. If governments continue to conduct current policies, global energy demand is expected to exceed $50 \%$ over current levels in 2030 [17]. The demand for natural gas, driven by electricity generation, would grow faster by $2.1 \%$ per year to reach 4.800 billion $\mathrm{m}^{3}$ in 2030 against 2.700 billion $\mathrm{m}^{3}$ in 2003. Gas will outweigh the coal and will be the second largest primary energy source by 2015 [15-17]. Fig. 1 shows the evolution of world consumption from 1995 to 2005. Global oil consumption was stable from 1995 to 2000 (38\%), then decreased to 1\% in 2005. Meanwhile, natural gas is consumed at a rate of $24 \%$ in 1995 and then remained stable from 2000 to 2005 (25\%). Moreover, coal was consumed at rates of 34\% (1995), 32\% (2000), and 34\% (2005). The hydroelectricity was consumed at a rate of $2 \%$ on an average between 1995 and 2005, while the renewable energy consumption remained low (less than $1 \%$ ) over the same period.

\subsection{Resource potential in Sub-Saharan Africa}

According to Karekezi [61], energy sector in Africa is best understood by three distinct regions: North Africa, which is heavily dependent on oil and gas; South Africa, which depends on coal; and the rest of Sub-Saharan Africa, which is largely reliant on biomass. In Africa, most of the substantially rich renewable energy resources are under-exploited. Until now, only about $7 \%$ of the enormous hydro potential has been exploited. However, this estimate does not include some of the significant small, mini, and micro-hydro opportunities. 


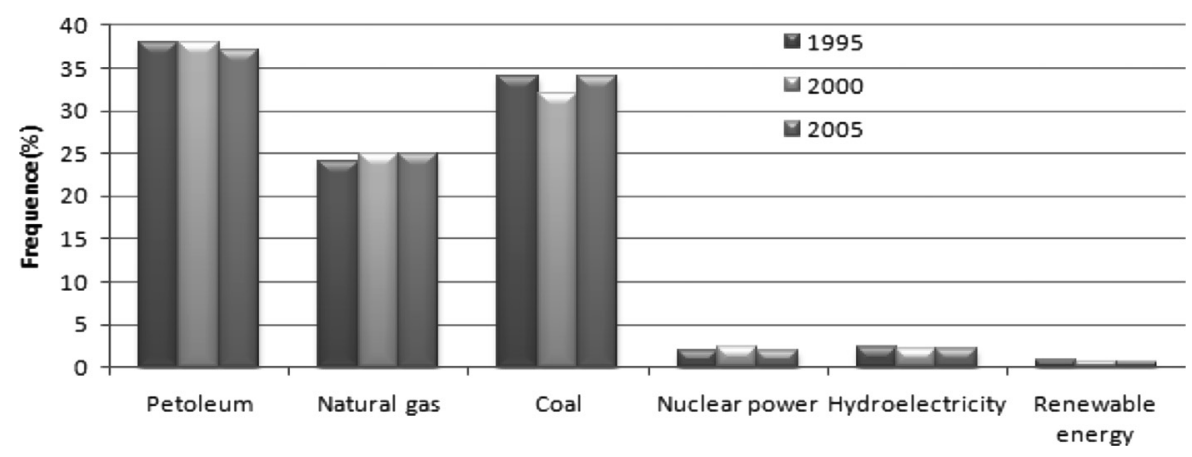

Fig. 1. Evolution of world consumption from 1995 to 2005.

Moreover, in Kenya, from 9000 MW of geothermal energy potential that stands, only about $60 \mathrm{MW}$ has been utilized [60]. Many other countries used geothermal energy, but at low scale. In 1999, the total energy demands for the Sub-Saharan Africa were approximately 267 Mtoe among which 54\% was traditional energy, 27\% oil, 14\% solid fuel, $3 \%$ hydropower, and $2 \%$ was gas [62,63].

\subsubsection{Electricity}

Sub-Saharan African countries use on an average seven times less electricity than those living in high-income countries [68]. Overall, 56\% of total energy use comes from traditional biomass, mainly firewood. Moreover, more than $83 \%$ of the rural population has no access to electricity. This rate was $92 \%$ in some Sub-Saharan African countries and $70 \%$ for South Asia [68]. In 2002, 34\% of electricity production came from oil, 27\% and 38\% came from hydro and gas, respectively. Only $1 \%$ came from geothermal electricity; $45 \%$ of this energy came from South Africa, 31\% from North Africa, and 24\% from the rest of Africa [64,65].

\subsubsection{Fossil fuels}

According to the estimates, the total oil production in 1997 was 8.1 million barrels per day, which was mainly from West and North Africa [68]. However, the total oil consumption was 2 million barrels per day, which is expected to double by 2010. In Africa, North Africa accounts for $50 \%$ and Nigeria for $30 \%$ of its gas reserves. However, South Africa accounts for about $90 \%$ of the continent's economically attractive coal reserves $[61,68]$.

\subsubsection{Renewable energy}

In Africa, because of the limited policy interest and investment levels, the renewable energy resource potential has not been fully exploited. Africa, with substantially rich renewable energy resources, has $1.1 \mathrm{GW}$ of hydropower capacity. It also has abundant biomass, solar, and significant wind potential $[67,68]$. In case of total electricity production, the share of hydroelectric power remains low (barely 7\% of the exploited potential). Water resources alone can cover all the electricity needs of Africa [60]. Solar energy remains poorly exploited for the production of heat and electricity in the Sub-Saharan Africa. However, the promotion of solar photovoltaic (PV) technologies has been very important in the region and currently almost every country in the Sub-Saharan Africa has a large PV project [69]. Moreover, in several countries large-scale wind generation projects are under development to utilize their abundant energy resources that are available. However, the wind capacity in operation is very low compared to more than 75,000 MW installed globally [69]. Biomass as the energy source still plays a dominant role in the African energy sector. The strong dependence vis-à-vis the biomass is particularly evident in Sub-Saharan Africa, where it represents 70$90 \%$ of the primary energy supply in some countries, and according to estimations, $86 \%$ of energy consumption [61].

\subsection{Overview on Cameroon}

Cameroon is located in the western part of Central Africa. Its neighboring countries are Nigeria, Chad, Central African Republic, Republic of Congo, Gabon, and Equatorial Guinea (CIA). French Cameroon became independent in 1960 and merged with southern British Cameroon in 1961. In 2008, the oil resources of Cameroon were estimated to be 30 million ton and natural gas reserves to be 186 billion $\mathrm{m}^{3}$ [17]. Cameroon has $20 \mathrm{GW}$ fair hydroelectric potential, which is exploited at less than 5\% [18]. Furthermore, Cameroon has the second largest forestry potential in the Congo Basin, unevenly distributed between the North and South of the country. The necessity to develop the energy infrastructure is a priority of the government's energy policy and to hire an ambitious program which intends to triple the energy capacity by 2020, which is about 3000 MW as against $1022 \mathrm{MW}$ in 2009 in the public facility [16]. In 2009, energy production was estimated to be 9016 ktoe in which more than 51\% was coming from biomass, $45 \%$ from oil, and only $4 \%$ from electricity [18]. Electricity generation is dominated by hydro (69\%), followed by self-production (22\%). The total installed electric power increased from $932 \mathrm{MW}$ in 2000 to $1558 \mathrm{MW}$ in 2009 [18], with a production potential of 103 terawatt-hours (TW h) per year. There are three main facilities in the country: EDEA (263 MW), Songloulou (388 MW), and Lagdo (72 MW) [28]. The potential for small hydroelectric power installations (up to $1 \mathrm{MW}$ ) is estimated to be $1.115 \mathrm{TW}$ h, mainly in the eastern and western regions of Cameroon; however, this potential is yet to be properly exploited. The biomass production in 2009 is estimated to be thirteen 118 KTM consisting almost entirely of firewood [16]. Utilization of palm oil for biodiesel is also a viable prospect for the country. At present, around 108,000 hectares (ha) of land are affected by palm oil crop. However, between 2001 and 2006, a total of 30,000 ha of forest were cleared to allow for the expansion of palm oil crop [25]. Cameroon is a small oil producer with a decline in production $(84,000$ barrels per day in 2008) after reaching a peak of about 168,000 barrels per day in 1985 . Cameroon has the second largest African hydropower potential (294 TW h) after the Democratic Republic of Congo, less than $4 \%$ shall be recovered to date $[19,20]$. The exploitable potential is nevertheless considerable: $19.7 \mathrm{GW}$ for an average energy production of $115 \mathrm{TW}$ h per year. Its potential for renewable energy (firewood, agro-industrial and forestry waste, and solar and wind energy) is also considerable [21]. In the northern part, facing the advancing desert, wood energy deficit is noticeable. The average insolation in the northern part of the country is $5.8 \mathrm{~kW} \mathrm{~h} / \mathrm{m}^{2} /$ day and in the southern part, the average insolation is $4 \mathrm{~kW} \mathrm{~h} / \mathrm{m}^{2} /$ day. Thus, there is an average insolation of $4.9 \mathrm{~kW} \mathrm{~h} / \mathrm{m}^{2} /$ day for the whole country [22-24]. This solar potential is sufficient for the development of energy uses. The national average is estimated at a theoretical $2327.5 \mathrm{TW} h$, about 20 times the hydroelectric potential [70]. The wind potential 


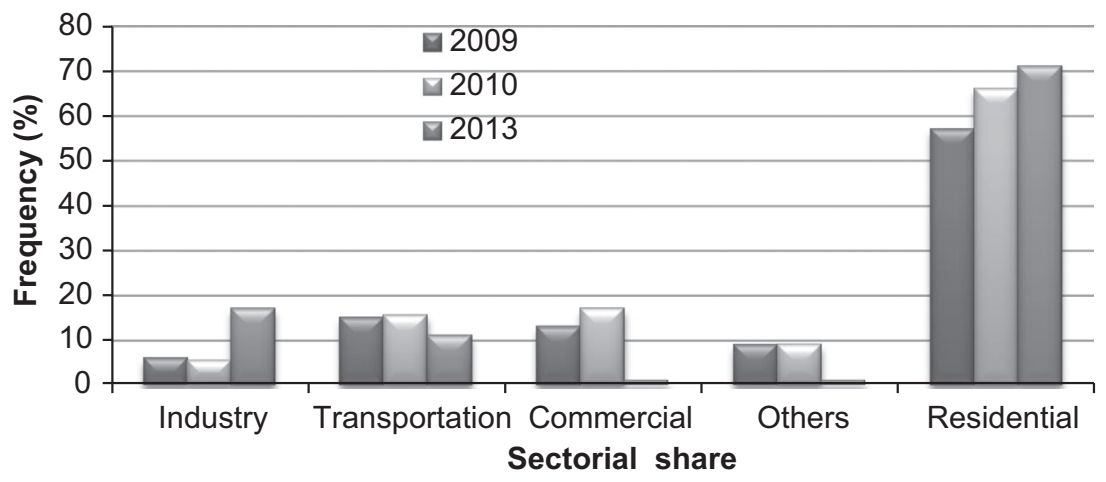

Fig. 2. Sectorial shares of global energy consumption in Cameroon [17,24].

is rather low for the energy production. Wind speeds on the entire territory hardly reach $5 \mathrm{~m} / \mathrm{s}$. Most of the country has wind speed average of $2-4 \mathrm{~m} / \mathrm{s}$ at the height of $100 \mathrm{~m}$. Wind energy potential exists in the north of Cameroon and the littoral region. Northern areas have average wind speed of $5-7 \mathrm{~m} / \mathrm{s}$. With regard to the geothermal energy, up to now, its potential is unknown, but hot springs are found in many cities of the country. Deposits of natural gas were estimated to be 186 billion per $\mathrm{m}^{3}$ [70].

\subsubsection{A strong demand for energy for its development}

Final energy consumption is of the order of 6 million toe, with $73 \%$ of biomass and $27 \%$ of commercial energy consumption (electricity and petroleum products) [18], which is still negligible compared to the country's energy potential. The final energy consumption per capita was 0.30 toe/capita, which is well below the African average (0.49) and the global (1.26) in 2009. A major increase in petroleum products is observed between 2008 and 2009 , which is equivalent to the increase observed during 20002008. This phenomenon can be explained in part by poor water conditions in 2009, which led to an increase of self-production and second, in parallel, we observed the increase in road fuel consumption [17,18]. Fig. 2 shows sectorial shares of global energy consumption in Cameroon. Energy consumption for the residential sector is about $70 \%$ of the total energy consumption, which is high compared with other developing and emerging countries [24]. This is a proof that comparatively, industrialization is limited in Cameroon. These results varied according to different countries. Payam et al. [5] showed that the residential sector constitutes to be the third largest major energy consumer in the world representing $27 \%$ of the total consumption. In France, buildings are the largest consumer of energy sector, which corresponds to almost $40 \%$ of the national consumption [30]. A tertiary building consumes $211 \mathrm{~kW} \mathrm{~h} / \mathrm{m}^{2} /$ year on an average [29]. In Malaysia, according to Kwong and Yusoff [3], the energy consumption of buildings comprises $13 \%$ of the total energy use which is expected to rise in the future. In Thailand, buildings account for the largest sector comprising $53 \%$ of the total electricity consumption. Over half of this consumption is due to the large commercial buildings [49]. Energy consumption is also very important in industry and transportation. In 2009, total energy utilized in different sectors increased up to $10 \%$ compared to the previous year (see Fig. 3). In the industrial sector, oil products and electricity consumed were 123.2 and 233.9 ktoe, respectively. No traditional biomass was used in this sector. In addition, 845.5 ktoe of oil produced was used in the transportation sector. Finally, in the residential sector, $73.4 \%$ (3785.6 ktoe) of the energy consumption comes from the traditional biomass, while oil products consumed was 123.7 ktoe. Only 77.6 ktoe of electricity was consumed in this sector. With regard to the primary energy supply in $2009,89 \%$ of the primary

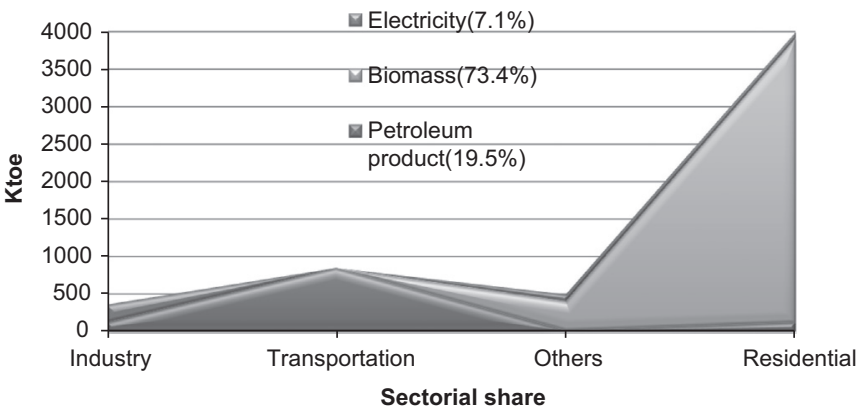

Fig. 3. Energy consumption in Cameroon (2009).

energy comes not only from combustible renewables and wastes but also from crude oil. In addition, $5 \%$ of the primary energy supply is natural gas, while $3 \%$ alone comes from hydroelectricity (see Fig. 4a). In 2009, for a total consumption of oil products of 12.9 TW h, (Fig. 4b), $76 \%$ of it was used in transport sector, $22 \%$ in residential and industrial sectors with an equal distribution of each one of these sectors. The commercial sector consumed only $0.3 \%$ of the oil products. An analysis of these different results shows that the transport sector consumed more than half of the oil products [26]. The electricity production was estimated to be 5741 gigawatt-hours (GW h) in $2009[17,18]$ in which $70 \%$ of this energy comes from hydroelectricity, $22.5 \%$ and $7.0 \%$ from oil and natural gas. Only $0.5 \%$ of the electricity production came from the renewable energy. In contrast, in 2010 , up to $10 \%$ of the total electricity production came from the natural gas products. Electricity rate coming from the "oil products" decreased to $5 \%$, while the renewable energy increased to $2 \%$ compared to the previous year.

Fig. 4c shows electricity consumption by various users between 2009 and 2010.

Around $44 \%$ and $43.5 \%$ of the electricity production was consumed between 2009 and 2010 in the industrial sector. In the residential sector, the consumption was $18 \%$ in 2009 with an increase of $5 \%$ in 2010 as compared to the previous year. In the commercial and public services, electricity consumption varied from $15 \%$ (2009) to $19 \%$ (2010). Cameroon's sectorial $\mathrm{CO}_{2}$ emissions in 2008 are shown in Fig. 5 [26]. The rate of $\mathrm{CO}_{2}$ emission in the transport sector was $54 \%$, in addition to $36 \%$ and $9 \%$ of $\mathrm{CO}_{2}$ rate of emission in the industrial and residential sectors.

\subsubsection{Global status of residential energy consumption}

The residential sector constitutes the third largest major energy consumer in the world representing $27 \%$ of total consumption $[5,27]$. Total world energy utilized in the residential sector reached 2074 Mtoe in 2010, a 14\% increase from 1819 Mtoe in 2000 [5]. In 
a

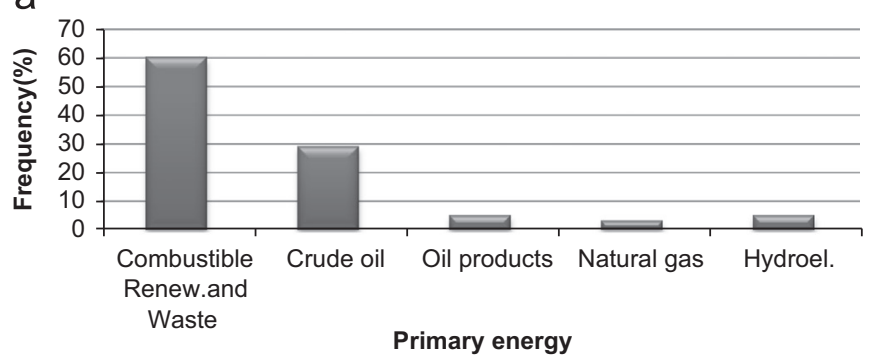

b

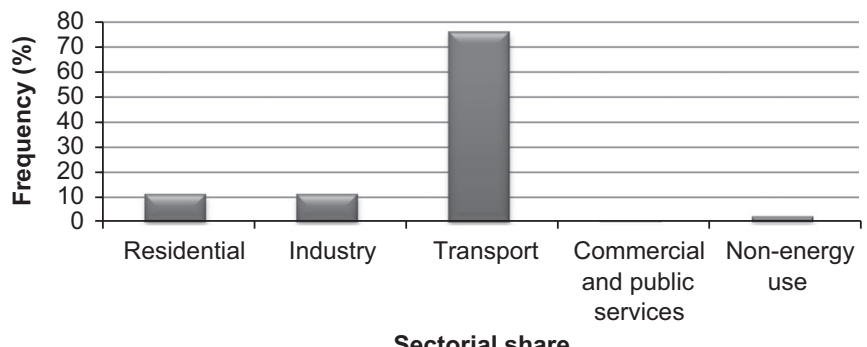

C

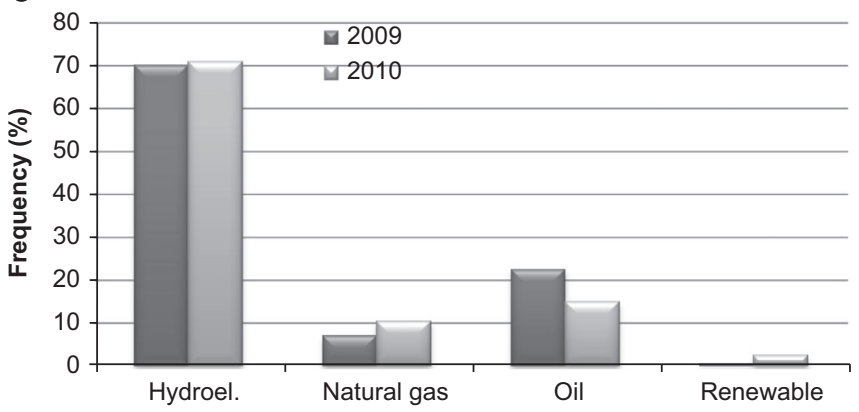

d

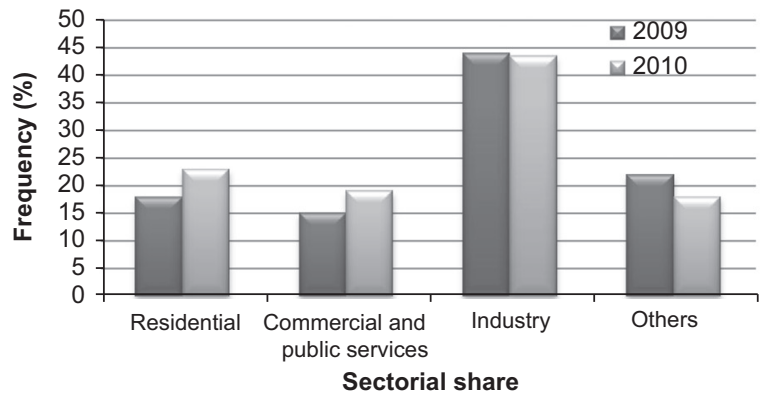

Fig. 4. (a) Primary energy supply in Cameroon (80.6 TW h). (b) Sectorial oil product consumption in Cameroon $(12.9 \mathrm{TW}$ h). (c) Electricity production in Cameroon (5741 GWh). (d) Electricity consumption by various users.

Cameroon, in 2010, the residential sector constituted the largest major energy consumer with a frequency of $66 \%$. Biomass consumption in the residential sector is around 94\%, which is considered to be the most consumed biomass energy in the residential sector. Many centuries ago, the traditional biomass was the main energy consumption in the world. Today, the strong increase of the population involves a great energy consumption demands in buildings. More traditional biomass is changed by modern energy or renewable energy. At present, traditional biomass is the main source of fuel in Cameroon [5]. In 2009, in Cameroon, 3987 ktoe of energy was consumed in the residential, with $95 \%$ of this energy coming from the traditional biomass; oil products were consumed at $3 \%$. About $2 \%$ of energy consumption alone came from electricity (see Fig. 6). Oil products are the second

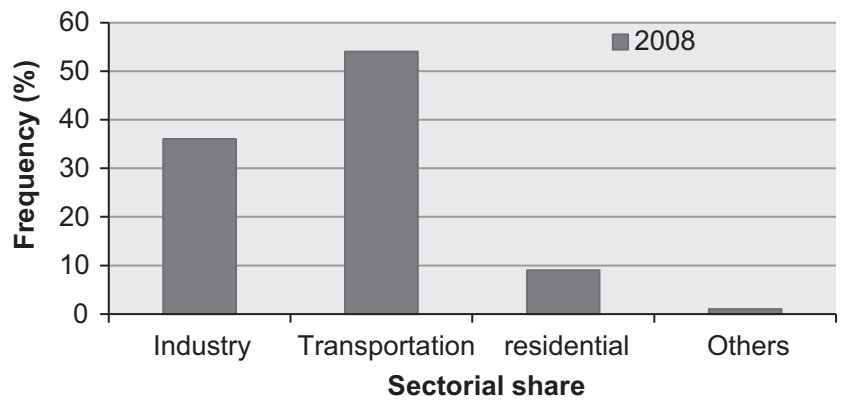

Fig. 5. Cameroon sectorial $\mathrm{CO}_{2}$ emission in 2008 [26].

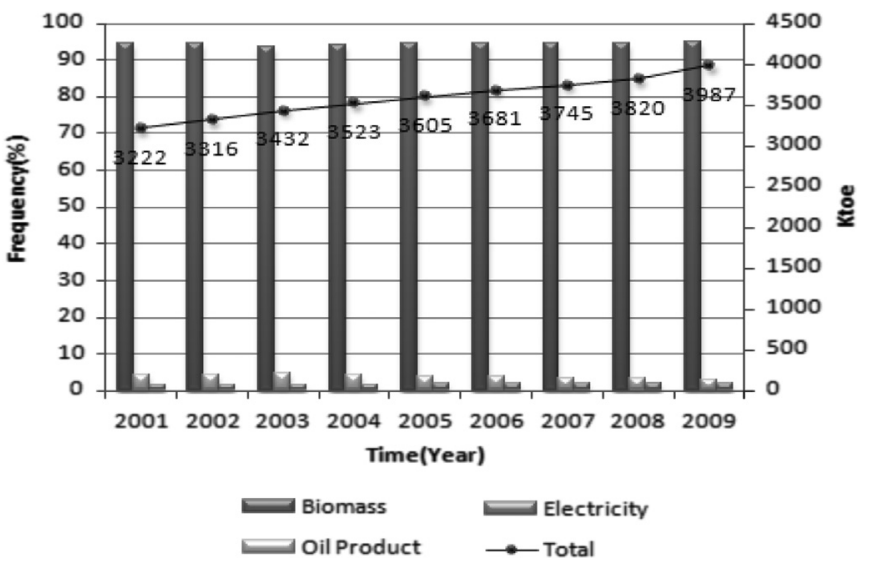

Fig. 6. Energy consumption in Cameroon residential sector (2009).

largest source, accounting for more than 5\% of energy utilization today in the residential sector [26].

An energy consumption demand in the residential sector, ever growing, was estimated to be 3.222 Mtoe in 2001, increased up to 3.820 Mtoe in 2008.

2.3.2.1. Final biomass consumption. Distribution of the final biomass consumption in the residential sector in 2009 is shown in Fig. 7. Between 2000 and 2009, 33.5 Mtoe of biomass was consumed in the residential sector. About 95\% of this energy consumption comes from wood. The remaining was distributed at a rate of $3 \%$ and $2 \%$ for coal and shaving, respectively. There is an increase of energy consumption demand every year in the buildings because, in 2000, the energy demand was 2.957 Mtoe [18-19]: an increase of 172 ktoe in 2002 compared to 2000; 183 ktoe in 2004 compared to 2002; an increase of 164 ktoe in 2006 compared to 2004; and finally, the biomass energy consumption demand, with an increase of $2 \%$ in 2008 compared to 2000 . An analysis of these different results shows that "wood" was the most consumed biomass, while "shaving" was the least consumed.

2.3.2.2. Oil product consumption. Fig. 8 shows the consumption of oil products between 2001 and 2009 in the residential sector. About 1.227 Mtoe of oil product was consumed in the residential sector, with $69 \%$ of it being "paraffin" and $31 \%$ of natural gas. Therefore, paraffin was the most used oil product in the residential sector of Cameroon. Oil products' demand increased between 2001 and 2003, where a peak was obtained at 160 ktoe; beginning of 2004, we noted a slight demand for oil products in the residential sector. From 2004 to 2009, the oil products consumed in the residential sector decreased to $3 \%$. Natural gas demand increased to 18\% between 2001 and 2009. 


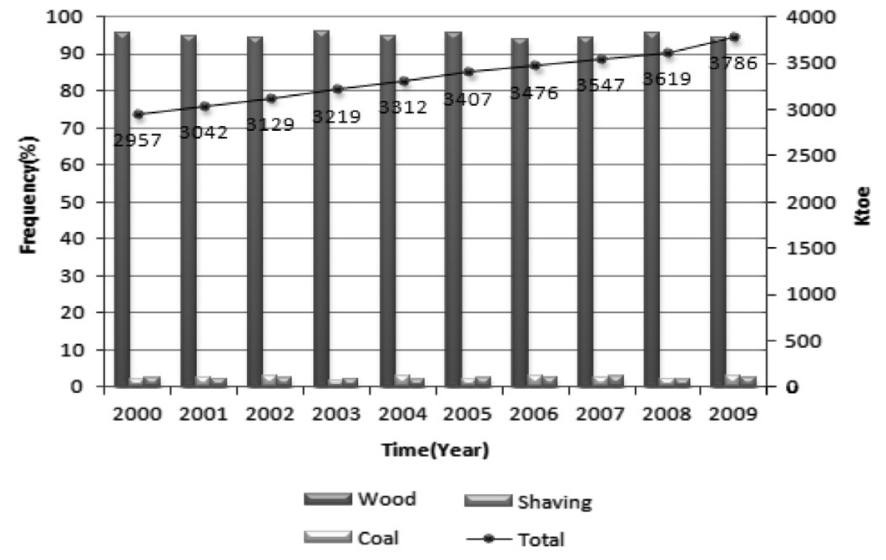

Fig. 7. Distribution of the residential biomass final consumption (2009).

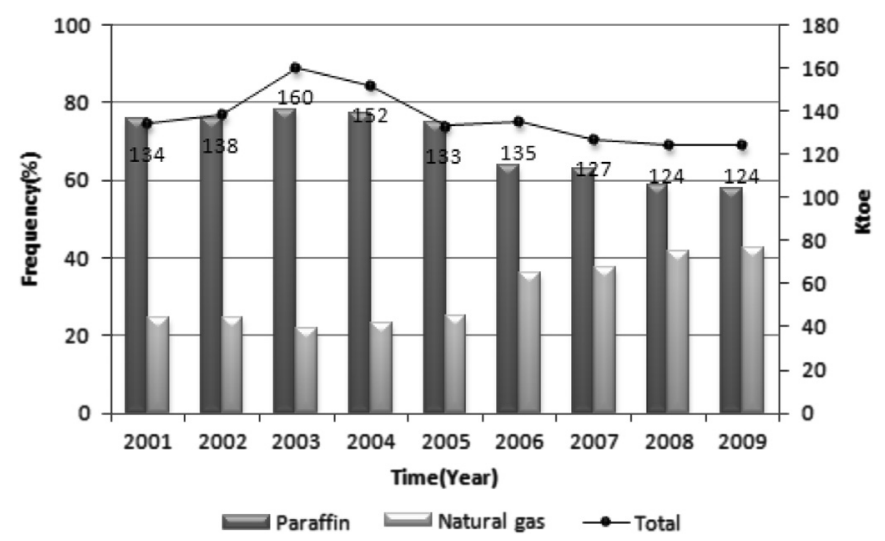

Fig. 8. Petroleum product consumption in the Cameroon residential sector:

2.3.2.3. Final electricity consumption. Electricity demand in the residential sector is only a small part of the total energy consumption. Electricity consumption has dropped during the period of 2002-2003, which was due to the shortages. However, during 2003-2006, a high consumption in electricity was noted. Recurrent power cuts have forced households to use alternative sources of energy.

\subsubsection{Access to electricity and living conditions of households}

In Cameroon, the rate of access to electricity increased from $46.8 \%$ in 2001 to $48.2 \%$ in 2007 [21]. In 2001 and 2007, the rate of access to electricity was $88.2 \%$ and $90.4 \%$ in urban areas, respectively. In general, access to electricity is high in areas where the incidence of poverty is low and vice versa. Of the 10,670 nonelectrified rural areas, $60 \%$ have an average population of less than 500 inhabitants, which is about $50 \%$ of the population [18]. Although Cameroon is experiencing a significant growth, electricity represented only 7.3\% of Cameroon's energy consumption in 2012. One of the main reasons for this low ratio is the country's low electrification rate. This increased from $49.7 \%$ to $57 \%$ between 2005 and 2011, thanks to the government's efforts to extend and increase the density of the electricity network [55].

\subsubsection{Energy efficiency in the electricity sector in Cameroon}

In Cameroon, the industrial sector includes all major sectors as well as the secondary subsectors such as electricity, gas, water distribution, and civil works. The energy efficiency scenarios reveal that potential electricity savings (between 20\% and 30\%) are attainable in the industrial sector by the year 2025. Technically energy-efficient measures are about to generate nearly $50 \%$ of the projected savings in the industrial sector [55]. Furthermore, the annual electricity production potential in agribusiness and woodprocessing industries is equivalent to around $700 \mathrm{GWh}$ of electricity, which corresponds to $140 \mathrm{MW}$ of electricity generation capacity. Therefore, in order to develop this amount of electricity generation an investment equivalent to that of a thermal power plant in required. With this aim, the development of a building energy quality code for all new buildings by imposing realistic specifications based on the state-of-the-art technologies and experience in construction is a pressing need in Cameroon. In the tertiary building sector, public buildings represent $37 \%$ of energy consumption, whereas other buildings account for the remaining 63\%. The work undertaken on energy efficiency scenarios has led to estimations of possible savings of $30 \%$ in electricity consumption in all of these buildings by 2025 [55]. This goal is particularly tangible for the public sector in which bringing down the cost of electricity bills is vital.

There are over 30 pieces of legislation that are likely to concern aspects related to energy efficiency, the principal ones being law No. 2011/022 of December 14, 2011, relating the electricity sector in Cameroon, and law No. 96/117 of August 5, 1996 relating to standardization [55]. There is the creation of the energy management cell by decision No. 121/97/MIMEE/DE of December 3, 1997; the creation of the regulatory agency for the electricity sector (RAELS) by decree No. 99/125 of June 15, 1999; the creation of Rural Electrification Agency (REA) by decree No. 99/193 of September 8, 1999 [70]. Law No. 2011/022 of December 14, 2011 regulating the electricity sector defines "energy efficiency" (Article 5 ) and grants the authority responsible for energy the power to organize electricity energy management activities as well as the conditions for the implementation of the national energy management program (Article 70.1). It paves the way for the rational use of energy while incorporating the notions of standards, energy efficiency monitoring, compulsory and regular energy audits, incentives and measures of encouragement, improved knowledge of the energy system, increased awareness among users, and so on. This law also entrusted RAELS with the implementation of the national electric energy management program that will be designed by the authority (Article 70.2) [57,58]. Law No. 2013/004 of April 18, 2013 establishes incentives for private investment, which stipulates specific measures favoring companies that contribute to the development of energy and water supply (ref. Article 14); Article 128 of the General Tax Code was modified by the Finances Law for 2012: value added tax (VAT) exemptions for solar or wind energy operating materials and equipment. It may also be noted that decrees No. 2013/203 and No. 2013/204 of June 28, 2013 regarding the organization and operation of RAELS and REA do not attribute a specific role in terms of energy efficiency to either of these institutions and that Law No. 96/117 of August 5, 1996 relating to standardization does not refer specifically to standards related to energy efficiency [5558].

\subsection{Overview on Madagascar}

Since 2011, electrical energy production has continued to increase in Madagascar. The total net production of electricity in Madagascar is $832,741 \mathrm{MW}$ h in 2001, to reach 1,267,647 MW $\mathrm{h}$ in 2011. Since 2001, the power energy production has increased to $50 \%$. The share produces by power plants was from 268,796 MW h in 2001, representing $32 \%$ of total production 577,302 in 2011 , representing $45.5 \%$ of total production [75]. Compared to this, production of hydropower plants reached 563,945 MW h in 2001 representing $68 \%$ of the total production to $690,337 \mathrm{MW}$ h in 2011 , representing $54 \%$ of the total production. Although in absolute terms the production of electricity increased by hydropower 
generation decreased compared to the contribution of production thermal power plants. The remaining share is very marginal and comes from solar energy as it does not exceed $8 \mathrm{MW}$ h. Madagascar has huge potential for solar power. In fact, it has an incident energy of about $2000 \mathrm{~kW} \mathrm{~h} / \mathrm{m}^{2} /$ year. And almost all the island regions have over $2800 \mathrm{~h}$ of sunshine a year. However, the most interesting regions have a radiation level greater than $5500 \mathrm{~W} / \mathrm{m}^{2}$. The areas suitable for wind farm installation are among other regions, north, where wind speed reaches $7.5-9 \mathrm{~m} / \mathrm{s}$, the southern regions with wind speed reaching 6-9 m/s, and the areas north and south along the East Coast, having a wind speed around $6.5 \mathrm{~m} / \mathrm{s}$ [76].

\section{Review on energy efficiency in building}

The effective use of energy is crucial due to the continuously depleting energy resources, especially for developing countries which are currently experiencing rapid economic and population growth [31]. Moreover, energy efficiency can reduce the bills for households and businesses thereby boosting the economy which will eventually be driving innovation in the process. Furthermore, the prospect of less energy consumption while achieving more is an exciting one [32]. Building energy standards and strategies are essential because of many invaluable benefits including ensuring energy-efficient design and sustained operations of buildings [33-35]. It is important to understand the special characteristics of the common areas in buildings for energy efficiency improvement while maintaining human comfort [31]. Energy efficiency is very important in the context of sustainable development because it contributes to energy savings and the reduction of $\mathrm{CO}_{2}$ emissions without undermining the welfare of building's occupants [36-39]. Efficiency standards appeal politically because they purport to conserve scarce resources while saving consumers' money a costless public policy [40]. The UK government revised Building Regulations in 2002, 2006, and 2010, towards more stringent energy efficiency standards and ultimately the target of "zero

Table 1

Building energy consumption [66].

\begin{tabular}{llll}
\hline Energyconsumption (\%) & Commercial & Residential & Total \\
\hline United States & 18 & 22 & 40 \\
United Kingdom & 11 & 28 & 39 \\
European Union & 11 & 26 & 37 \\
World & 07 & 16 & 24 \\
\hline
\end{tabular}

carbon" new homes from 2016 [41]. Building energy regulations, also referred to as building energy codes, emerged in the 1970s as an essential tool for improving energy efficiency and minimizing energy consumption in buildings. Basically, they aim at setting minimum energy efficiency requirements to achieve energyefficient design in new buildings [9]. Table 1 shows the weight of buildings' energy consumption of several countries reported by International Energy Agency in 2004. From the table, it can be seen that in the United Kingdom, building energy consumption has increased at a rate of $0.5 \%$ per annum and is responsible for $47 \%$ of national energy consumption. In the literature, we can get many works concerning energy efficiency in building. Chua and Chou [10] show correlations that will predict building heat gains and cooling energy consumption for commercial buildings in tropical climates. Comparing estimated and simulated results, they were found to have a good agreement, even for buildings having different aspect ratios. A design-day weather file was employed to provide simplicity, flexibility, and greater ease of use. Levinson [40] explained why the electricity consumption in residences in California has been stable since 1970, while in other states, the demand for electricity is steadily increasing. The growing gap between California and other states demonstrates that other states and countries could replicate California's gains by adopting California-style regulations and that California should build on its own success by tightening its standards further. Fig. 9 shows the residential electricity use per capita 1963-2009. Pan and Garmston [41] carried out a study, with an aim to reveal the levels of compliance with energy. Building Regulations of new-build dwellings in England and Wales, explore underlying issues and identify possible solutions. In total, 376 new-build dwellings were investigated. The compliance revealed was poor, at a level of $35 \%$, accompanied by $43 \%$ "grey compliance," and $21 \%$ "grey noncompliance" (due to insufficient evidence of achieving required carbon emission reductions). Exploring these issues reveals a complex system of factors influencing energy regulations compliance, which involves a wide range of stakeholders. These results should inform the formulation and implementation of energy-efficient building regulations and policies in the future. Ambrose et al. [42] analyzed the life cycle primary energy use of a wood-frame apartment building designed to meet the current Swedish building code. These analyses included the primary energy use during the production, operation, and end-of-life phases. As a result, it has been found that an electric heated building built to the current building code has greater life cycle primary energy use relative to a district heated building, although the standard for electric heating

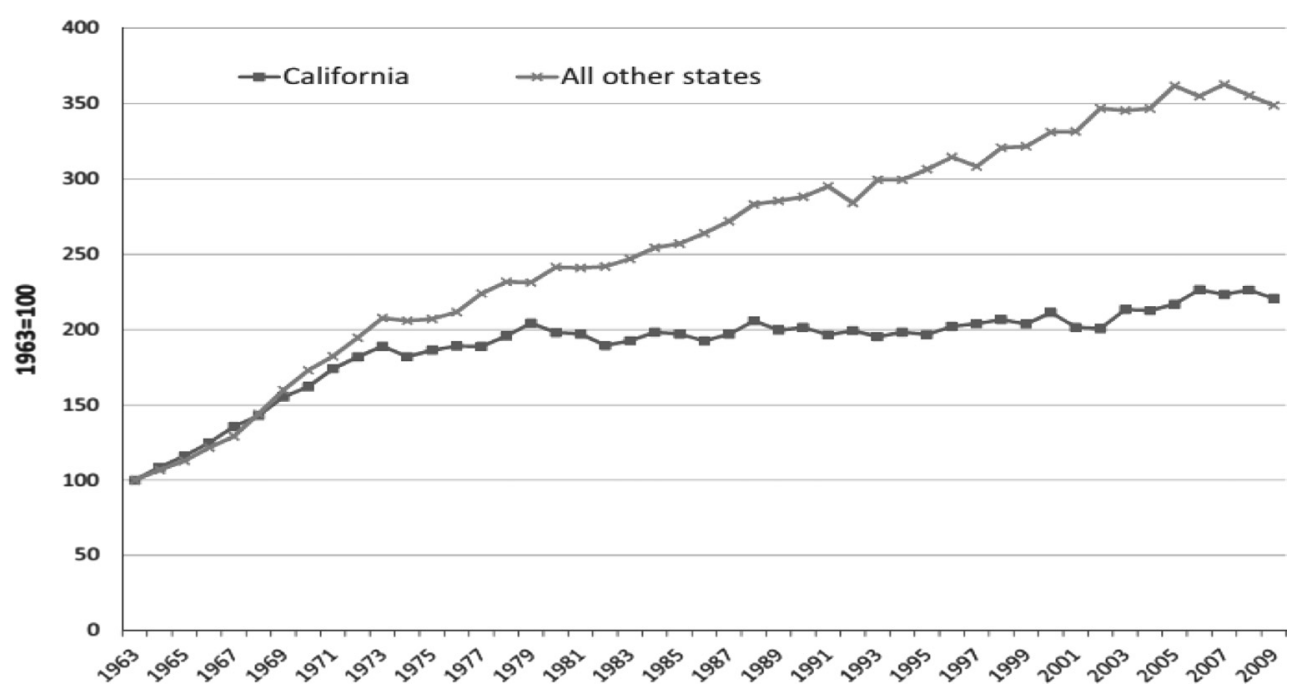

Fig. 9. Electricity consumption in the residential sector in the world [40]. 
is more stringent. Also, the primary energy use for an electric heated building constructed to meet the passive house standard is substantially higher than for a district heated building built to the Swedish building code of 1994.

Primary energy use to extract, process, and transport the materials can be calculated thanks to Sathre's [43] equation:

$E_{\text {production }}=\sum_{i}\left\{\sum_{k}\left[F_{i, k} \mid X\left(1+\alpha_{k}\right)\right]+\frac{L_{i}}{\gamma}+B_{i}\right\}$

where $E_{\text {production }}$ is total primary energy use for material production $(\mathrm{kW} \mathrm{h}) ; i$ is individual types of materials in the building; $F$ is end-use fossil fuel energy used to extract, process, and transport the materials ( $\mathrm{kW} \mathrm{h}) ; k$ is fossil fuels: coal, oil, and natural gas; $\alpha$ is fuel cycle energy requirement of the fossil fuel; $L$ is end-use electricity to extract, process, and transport the materials $(\mathrm{kWh}) ; \gamma$ is conversion efficiency for electricity production; and $B$ is heat content (lower heating value) of the biofuels used in material processing ( $\mathrm{kW} \mathrm{h}$ ).

Evans et al. [44] have shown and explained the trends and status of rural building energy use in China. They provide an overview of the new rural building design standard and describe options and issues to move forward with implementation. Rural

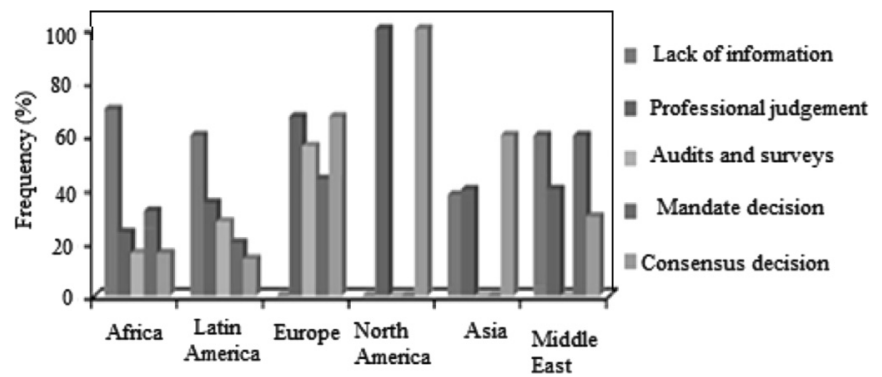

Fig. 10. Regional building energy standard development performance [45]. buildings in China represent a significant opportunity for improved energy efficiency, reducing emissions and improving local development. Currently, in China, more than half of all building energy consumption is in rural buildings. Iwaro and Mwasha [45] investigated the progress of building energy regulations in developing countries and its implication for energy conservation and efficiency. Their study revealed that the present progress made on building energy regulations in relation to implementation, development, and compliance recommends solutions to the barriers facing building energy regulation implementation in the developing countries.

Fig. 10 shows the regional building energy standard development performance [45].

Motawa and Oladokun [46] explored the intrinsic interrelationship between the dwellings, occupants, and environment systems. The study identifies "cause and effect" relationships among these systems as well as quantitatively simulates the behavior of the household energy consumption and $\mathrm{CO}_{2}$ emission (HECCE). They suggested a system dynamics to utilize the hard and soft data incorporated in this system with due cognizance to the interdependencies of variables that are involved in addition to mental judgment of the experts and industry practitioners. The proposed model provides policymakers with a decision-making tool upon which different scenarios regarding HECCE can be tested before implementation. The outcome of this study has similar implications for the society. However, the model needs to include other variables to improve its robustness. The model validation tests have approved its credibility and sensibility to the variation in key variables. Table 2 shows the categories of variables included in the studied model at this stage [46]. Groesser [47] shows how technological, social, political, and economic factors interact and shape the evolution of the energy efficiency in building codes. First, a qualitative, structural model is demonstrated, which endogenously formalizes the IDS dynamics of standard improvement. He found that the co-evolution of voluntary and legal building codes has

Table 2

Modes boundary [46].

\begin{tabular}{|c|c|c|}
\hline Endogenous variables & Exogenous variables/parameters & Excluded variables \\
\hline Heat losses & Household size & Variables related to occupants \\
\hline Dwelling heat gain due to cooling & Total floor area & Behavior \\
\hline DHG due to no. of people & Area of opening & Occupants' social class influence \\
\hline DHG due to appliances' less cooling & Solar flux & Occupants' social group influence \\
\hline DHG due to artificial lighting & Solar transmittance & Occupants' cultural influence \\
\hline Average effect of solar gains & Frame factor & Occupants' personal influence \\
\hline Total dwelling heat gains & Average solar access facto & Variables related to dwellings ph. \\
\hline Natural heat transfer & $\mathrm{Pi}$ & Parameters: \\
\hline Artificial heat transfer & DHG due to water heating & Dwelling exposure \\
\hline Dwelling internal heat & Insulation factor & Dwelling orientation \\
\hline Discrepancy in internal and external temperature & Set-point temperature & Air changes \\
\hline Dwelling internal temperature & conversion factor & Variables related to external \\
\hline Discrepancy in internal and set-point temperature & Growth in occupants' activity level & Environment: \\
\hline Humidex value & External air temperature & New technologies \\
\hline Occupants' activity level & Relative humidity & Political uncertainties \\
\hline Occupants' metabolic build-up & SAP rating & Energy securities \\
\hline Perceived dwelling temperature & Average annual gas bill & \\
\hline Occupants' comfort & Average annual electricity bill & \\
\hline Probability of window opening & Energy with no carbon conversion factor & \\
\hline Probability of putting on clothing & Carbon depletion factor & \\
\hline Effect of energy efficiency standard improvement & Demand for cooling energy & \\
\hline Energy efficiency & Lighting energy demand & \\
\hline Effect of fabric insulation on energy efficiency & Appliances energy demand & \\
\hline Effect of combined fabric insulation and energy efficiency & Population equilibrium time & \\
\hline On dwelling energy efficiency & Reproductive time & \\
\hline Effect of energy efficiency standard on cooling $E$. & Average total fertility rate & \\
\hline
\end{tabular}


Table 3

Literature summary for thermal energy storage in the residential buildings [48].

\begin{tabular}{|c|c|c|c|c|}
\hline Storage & Studied buildings & Methodology & Focus of studies & Main results technique \\
\hline Passive sensible & Single family houses & Simulations & Energy savings & Most studies report small energy \\
\hline Passive latent & Single family house & Simulation and & Comfort and peak & Reduction of excess temperature \\
\hline Storage & Small multifamily & experiments & Reduction & Cooling and heating demand \\
\hline Sensible storage & Apartment buildings, & simulation & Emission reduction & Heating peak load for boilers \\
\hline Latent storage in & Single family houses & Simulations & Improved indoor & Considerable reduction of excess \\
\hline $\begin{array}{l}\text { Thermochemical } \\
\text { Storage }\end{array}$ & Single family houses & Simulations & Switch in energy source & Long terms storage with minimum \\
\hline Distribution & House. Low energy & building & Reduction & Significant peak shaving. \\
\hline
\end{tabular}

enabled a continuous improvement of the standards even in the absence of economic pressures. In addition, the model for policy analysis is presented, which indicates that several obvious policies might cause policy resistance and could result in uneconomical, counter-intuitive outcomes. Heier et al. [48] demonstrated that thermal energy storage (TES) was a technology that could have positive effects on the energy efficiency of a building by contributing to an increased share of renewable energy and/or reduction in energy demand or peak loads for both heating and cooling. His results showed many promising TES technologies, both for residential and commercial buildings. Table 3 shows a summary of the literature treating the use of TES in residential buildings. The literature presented in this table specifically includes studies on residential buildings. Li et al. [50] used a techno-economic analysis approach, to investigate the optimal choice of building energy efficiency (BEE) standard in the context of centralized urban district heating system in northern China. It was found that BEE improvements in northern Chinese cities are more cost-effective than investing in low-carbon technologies such as wind power or Carbon Capture and storage in the European Union and United States with regard to $\mathrm{CO}_{2}$ emission mitigation. Financing should not be a major barrier to BEE improvement in the Chinese cities provided that efficient institutions will be established. Improving building energy performance can produce effective benefits compared with the business as usual case. At European level, a significant number of directives and laws related to energy efficiency have emerged in European Union, among these, the main policy driver related to the energy use in buildings is the Energy Performance of Buildings Directive (EPBD, 2002/91/EC), implemented in 2002 and updated in 2010 (EPBD recast, 2010/31/EU) with more ambitious provisions [51]. Sameer and Mutasim [52] used eQUEST software to examine the energy performance of the chosen buildings and to evaluate the energy-saving potential after applying Estidama requirements. The results of energy simulation of the chosen buildings showed a potential of electricity reduction between $31 \%$ and 38\% depending on the building type and other parameters. In Abu Dhabi, 84.6\% of electricity product is used in the commercial buildings and residential sector. The majority of its electricity is jointly produced from cogeneration plants. Lu et al. [53] investigated the barriers which impede the promotion of Energy Efficient Building to suggest the solutions to alleviate these barriers by capturing the benefits from Clean Development Mechanism (CDM) in China. The limited awareness of CDM implies that corresponding policies should be formulated and implemented to improve the capability of providing more EEBs with CDM. The promotion of EEB needs a holistic approach based on the concerted collaboration of government, mass media, international and national green building institutions, building professionals, developers, financial institutions, and endusers. Farshid et al. [54] have developed a building energy simulator software tool in order to simulate a sample society of office buildings. They conducted a widespread field activity in order to gather the data modeled from 285 office buildings through all the four climatic zones in Iran.

\subsection{Energy policies and codes of Cameroon}

\subsubsection{Strategic goals for energy efficiency in the tertiary building sector}

In Cameroon, the energy demand from tertiary building sector represents $20 \%$ of the demand for electricity on public networks ( $720 \mathrm{GWh}$ in 2012) which is forecasted to grow around 55\% between 2012 and 2025 [57]. Air-conditioned buildings are the major consumers in the tertiary building sector depending on the type of building and the materials used, representing between $45 \%$ and $60 \%$ of consumption [18]. A survey confirmed that the high consumption by the tertiary building sector in Cameroon is because of their poor initial design, a lack of maintenance, and the lack of awareness of the cost of running the air conditioning systems. Users of air-conditioning systems may monitor their behavior which may lead to the savings of energy (similarly for lighting). The energy audit is a pre-requisite for energy retrofitting buildings, with a particular view to introduce new and efficient air-conditioning, ventilation and lighting technologies [56-59].

An overview of the proposed measures is given in the following table with an implementation time frame (Tables 4 and 5).

\subsubsection{Strategic goals for energy efficiency in the residential sector}

The household demand for the electricity networks was estimated that to be $1.113 \mathrm{GWh}$ in 2012 [55]. Furthermore, there is a large discrepancy between urban and rural household electricity consumption in the residential sector. Only about $18.5 \%$ of households in the rural areas have access to electricity compared to $87 \%$ of the urban population [56,59]. With an estimated share of $30 \%$ of total energy consumption, the residential sector is the second highest consumer of electric energy in Cameroon [18]. To reduce the energy consumption lighting remains a strategic area and, above all, to limit peak power demand. On the contrary, the use of electrical appliances is ever increasing due of the increasing urbanization and also the improvement in income and standards of living. Therefore, the important issues would be how to efficiently use the household equipments. To do this, in Cameroon, minimum energy performance ratings must be established for all the domestic appliances, by referring to what is being done in other developed or developing countries. A specific approach may be developed with regard to air conditioning. In order to achieve this, consultation with private-sector stakeholders is highly necessary so that the implementation of accompanying measures which allows the effective application of regulations can be monitored. Table 6 shows the strategic goals for the residential sector concerning energy efficiency.

Setting a minimum standard for all buildings, regulatory controls can augment coexisting voluntary schemes [71]. The voluntary schemes can benefit from the increased awareness and drive towards improvements triggered by the regulations, use the regulatory requirement as a baseline for defining enhanced performance and provide an incentive for buildings to achieve a 
Table 4

Strategic goals for tertiary building sector [55].

\begin{tabular}{|c|c|c|}
\hline Strategic goals & Results & Reasoning \\
\hline $\begin{array}{l}\text { Improved energy efficiency } \\
\text { in new buildings }\end{array}$ & $\begin{array}{l}\text { A new energy efficiency code for the construction of buildings } \\
\text { is implemented and enforced. }\end{array}$ & $\begin{array}{l}\text { A building code that takes energy efficiency into account is the most } \\
\text { effective means of reducing energy consumption in new buildings. The } \\
\text { added cost of a construction in which design implement solutions to } \\
\text { make the new building intrinsically efficient is lower than the cost of } \\
\text { improving the energy efficiency of an existing building. The building code } \\
\text { establishes which designs improve energy efficiency. }\end{array}$ \\
\hline $\begin{array}{l}\text { Improved energy efficiency } \\
\text { in existing buildings }\end{array}$ & $\begin{array}{l}\text { In } 2018,60 \% \text { of the tertiary buildings have carried out an } \\
\text { energy audit, reaching } 100 \% \text { in } 2025 \text {. }\end{array}$ & $\begin{array}{l}\text { The energy efficiency of existing buildings may be improved in a cost- } \\
\text { effective manner by paying particular attention to how the building is run. } \\
\text { Promoting the position of on-site energy manager and measures to help } \\
\text { building owners finance energy audits and find financing for renovations } \\
\text { are ways to incentivize progress in this direction. }\end{array}$ \\
\hline $\begin{array}{l}\text { Improved energy efficiency } \\
\text { in public buildings }\end{array}$ & $\begin{array}{l}\text { The electricity bill of public buildings is reduced by } 20 \% \text { in } \\
2020 \text {. }\end{array}$ & $\begin{array}{l}\text { The concern of the government is to reduce its electricity bills in public } \\
\text { buildings. The implementation of an energy manager in public buildings } \\
\text { is strategic. The manager is responsible for liaising with the central } \\
\text { authority that manages all public buildings and is a driving force in terms } \\
\text { of improving the site and developing action plans to renovate the } \\
\text { building. They also supervise equipment, such as air conditioning, and } \\
\text { raise user awareness. }\end{array}$ \\
\hline $\begin{array}{l}\text { Improved education and } \\
\text { awareness of energy } \\
\text { efficiency in buildings }\end{array}$ & $\begin{array}{l}\text { Key professional players of the building sector (architects, } \\
\text { energy managers, etc.) apply energy efficiency principles on a } \\
\text { permanent basis. }\end{array}$ & $\begin{array}{l}\text { Architectural students are trained in the necessary fundamentals to } \\
\text { understand issues of energy efficiency in professional practice. } \\
\text { Professional architects are trained and informed in order to improve } \\
\text { energy efficiency in the construction of buildings. }\end{array}$ \\
\hline
\end{tabular}

Table 5

Action plan measures and implementation time frame [55].

\begin{tabular}{|c|c|c|}
\hline Goal & Description & $\begin{array}{l}\text { Implementation time } \\
\text { frame }\end{array}$ \\
\hline 1 & Setting up an energy efficiency data collection and documentation centre in buildings & ST \\
\hline 1 & Providing training on energy management to building managers in the private sector & ST \\
\hline 1 & Drawing up a program to optimize the efficiency of lighting, air conditioning and miscellaneous equipment & ST \\
\hline 2 & Appointing energy managers in public buildings & ST \\
\hline 2 & Optimizing electricity bills & ST \\
\hline 2 & Renovating electrical installations (lighting and air conditioning) & MT \\
\hline 2 & Improving the performance of air-conditioning systems through the introduction of energy performance standards & MT \\
\hline 3 & $\begin{array}{l}\text { Drawing up an energy efficiency building code for the construction of new buildings and national regulations for energy performance in } \\
\text { existing buildings }\end{array}$ & MT \\
\hline 3 & Creating or upgrading laboratories for testing and approving construction materials and developing a labeling scheme for such materials & MT \\
\hline
\end{tabular}

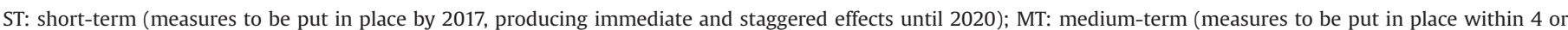

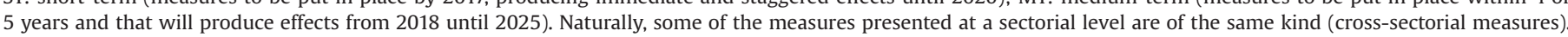

Table 6

Strategic goals for the residential sector and end-users $[55,58,59]$.

\begin{tabular}{|c|c|c|}
\hline Strategic goals & Results & Reasoning \\
\hline $\begin{array}{l}\text { Improved energy efficiency in electrical } \\
\text { appliances }\end{array}$ & $\begin{array}{l}\text { Households use more efficient products } \\
\text { to reduce their energy consumption }\end{array}$ & $\begin{array}{l}\text { There is much equipment in the domestic market that is not very efficient and has an } \\
\text { impact on peak consumption. No energy performance standard is applied in } \\
\text { Cameroon and users are not informed of the performance of the appliances available } \\
\text { in the market. It is recommended that minimum energy performance standards are } \\
\text { developed, that verification tests are undertaken by approved test laboratories and } \\
\text { that the energy labeling of equipment is gradually put in place. Once informed, the } \\
\text { consumers change their behavior and give more weight to energy performance in } \\
\text { their selection criteria. }\end{array}$ \\
\hline $\begin{array}{l}\text { Raised awareness of energy efficiency } \\
\text { issues by citizens as part of the daily } \\
\text { life }\end{array}$ & Behavioral change of end-users & $\begin{array}{l}\text { There is currently a lack of general energy-efficiency awareness at all levels. } \\
\text { Educational programmes must, therefore, be developed and incorporated into school } \\
\text { curricula. Advertising campaigns must be broadcast on radio and TV and run in } \\
\text { newspapers in order to inform the general public of the benefits: direct savings on } \\
\text { their energy bills and reduced government charges with impact on the fiscal pressure. }\end{array}$ \\
\hline
\end{tabular}

standard above the minimum [72]. Several codes on energy efficiency in buildings have already been adopted in most of the only developed countries such as United States, England, Canada, and also China as an emergent country. The Cameroonian government also had the example of these countries initiated and transmitted codes on the energy efficiency to its population. In the United States, the 1975 Energy Policy and Conservation Act (EPCA), was established in order to regulate and curb energy consumption and limit the dependence on imported oil. This law has been amended several times in accordance with the requirement of American Society of Heating Refrigerating and AirConditioning Engineers (ASHRAE) [73]. In the United Kingdom, 
Table 7

Financial resources required in Cameroon [55].

\begin{tabular}{|c|c|c|c|c|}
\hline Priority AREA & $\begin{array}{l}\text { Potential } \\
\text { (GWh) }\end{array}$ & Timing & $\begin{array}{l}\text { Saving } \\
\text { potential (\%) }\end{array}$ & $\begin{array}{l}\text { Financial } \\
\text { requirements } \\
\text { (public) }\end{array}$ \\
\hline \multirow[t]{2}{*}{ Industry } & \multirow[t]{2}{*}{1165} & $\begin{array}{l}\text { Short-term } \\
\text { actions }\end{array}$ & 90 & $30,800,000$ \\
\hline & & $\begin{array}{l}\text { Medium-term } \\
\text { actions }\end{array}$ & 10 & 275,000 \\
\hline \multirow{2}{*}{$\begin{array}{l}\text { Tertiary } \\
\text { building } \\
\text { sector }\end{array}$} & \multirow[t]{2}{*}{505} & $\begin{array}{l}\text { Short-term } \\
\text { actions }\end{array}$ & 43 & $7,250,000$ \\
\hline & & $\begin{array}{l}\text { Medium-term } \\
\text { actions }\end{array}$ & 57 & $11,700,000$ \\
\hline \multirow[t]{2}{*}{$\begin{array}{l}\text { Residential } \\
\text { and end use }\end{array}$} & \multirow[t]{2}{*}{280} & $\begin{array}{l}\text { Short-term } \\
\text { actions }\end{array}$ & 46 & $12,650,000$ \\
\hline & & $\begin{array}{l}\text { Medium-term } \\
\text { actions }\end{array}$ & 54 & $5,750,000$ \\
\hline \multirow[t]{2}{*}{$\begin{array}{c}\text { Electricity } \\
\text { system }\end{array}$} & \multirow[t]{2}{*}{300} & $\begin{array}{l}\text { Short-term } \\
\text { actions }\end{array}$ & 83 & $31,000,000$ \\
\hline & & $\begin{array}{l}\text { Medium-term } \\
\text { actions }\end{array}$ & 17 & \\
\hline Total & 2250 & & 32 & $101,900,000$ \\
\hline
\end{tabular}

the energy performance of buildings is enforced through Part L of the Building Regulations [74]. L1 version of the law, published in 2002, deals with conservation in housing and the Part L2 deals with other types of buildings. The British Standards and CIBSE Guides, which are amended periodically in response to changing needs and technologies, are well received by industry and are serving as practice guides for practitioners. Canada also introduced the Model National Energy Code for Buildings (MNECB) in 1999 [72], mandating energy consumption targets for space conditioning, lighting and service water heating.

\section{Social, economic, and environmental benefits in Cameroon}

Table 7 shows the financial resources required [55].

In 2025, the savings generated are $2250 \mathrm{GWh}$, which represent a reduction in consumption of $32 \%$. Public investment is estimated at $€ 101,900,000$. This allows us to have a benefit of $€ 30,800,000$ and $€ 2,750,000$ for the actions in short term and medium term.

\section{Conclusion}

Nowadays, despite many efforts by governments on energy consumption, demand for energy is constantly growing. Industries, commercial buildings, and residences are the main area where the energy is most consumed. This paper reviews the status and current trends of potential of the resources, energy consumption, and energy policies in the residential sector. In the developing countries, energy consumption increased by $14 \%$ during the last decade, which was mostly due to rapid urbanization, population growth, and economic development. The increasing demand of air conditioning and artificial lighting for the improvement of human comfort in the tropics also greatly contributes to the increase in energy usage. Energy efficiency can reduce the bills for households and businesses thereby boosting the economy, which will eventually be driving innovation in the process. In Cameroun, in 2010, the residential sector constituted the largest major energy consumer with a frequency of $66 \%$. Biomass consumption in the residential sector is around 94\%. Today, biomass energy is considered to be the most consumed energy in the residential sector.

\section{Acknowledgments}

The authors thank the administration of the University of Yaounde 1 (Cameroon) and the University of Antsiranana (Madagascar) and also the PAFROID (Partenariat inter-universitaire entre l'AFRiqueetl'OceanIndien pour le Developement) project for supporting this study.

\section{References}

[1] Boisson Pierre (sous la dir. de). Énergie 2010-2020: Les chemins d'une croissance sobre. Paris, La documentation Française; 1998.

[2] Organisation de Coopération et de Développement Economique (OCDE) et International Energy Agency (IEA). World Energy Outlook 2008, Résumé, 〈http://www.worldenergyoutlook.org/docs/weo2008/WEO2008_es_french. pdf .

[3] Kwong Qi Jie, Ali Yusoff. A review of energy efficiency potentials in tropical buildings - perspective of enclosed common areas. Renew Sustain Energy Rev $2011 ; 15: 4548-53$.

[4] Lombard L, Ortiz J, Pout C. A review on buildings energy consumption information. J Energy Build 2008;40:394-8.

[5] Payam Nejat, Fatemeh Jomehzadeh, Mohammad Mahdi Taheri, Mohammad Gohari, Majid Muhd Zaimi Abd. A global review of energy consumption, $\mathrm{CO}_{2}$ emissions and policy in the residential sector (with an overview of the top ten $\mathrm{CO}_{2}$ emitting countries). Renew Sustain Energy Rev 2015;43:843-62.

[6] Karekezi S, Ranja T. Renewable energy technologies in Africa. Oxford, U.K: ZED Books and AFREPREN; 1997.

[7] Mwasha Abraham, Williams Rupert G, Iwaro Joseph. Modeling the performance of residential building envelope: the role of sustainable energy performance indicators. Energy Build 2011;43:2108-17.

[8] Xu Pengpeng, Hon-Wan Chan Edwin, Kun Qian Queena. Success factors of energy performance contracting (EPC) for sustainable building energy efficiency retrofit (BEER) of hotel buildings in China. Energy Policy 2011:39:7389-98.

[9] José Ortiz Luis Pérez-Lombard, Coronel Juan F, Maestre Ismael R. A review of HVAC systems requirements in building energy regulations. Energy Build 2011;43:255-68.

[10] Chua KJ, Chou. SK. A performance-based method for energy efficiency improvement of buildings. Energy Convers Manag 2011;52:1829-39.

[11] Sartori Igor, Napolitano Assunta, Voss Karsten. Net zero energy buildings: a consistent definition framework. Energy Build 2012:48:220-32.

[12] Dodoo Ambrose, Gustavsson Leif, Sathre Roger. Building energy-efficiency standards in a life cycle primary energy perspective. Energy Build 2011;43:1589-97.

[13] Yu Sha, Eom Jiyong, Evans Meredydd, Clarke Leon. A long-term, integrated impact assessment of alternative building energy code scenarios in China. Energy Policy 2014;67:626-39.

[14] Agence Internationale de l'Energie. Energy Technology Perspectives; 2010.

[15] Commissariat général du Développement Durable. Les filières industrielles stratégiques de l'économie verte. www.developpement-durable.gouv.fr; 2010.

[16] MINFOF et FAO. Evaluation, des resources forestiéres du Cameroun; 2005.

[17] MINEE. Etude du marché de GPL, Cameroun; 2004

[18] MINEE. Systéme d'information énergétique du Cameroun, rapport 2010 and 2011.

[19] Ministère de l'Energie et de l'Eau (2006)-Plan de Développement à long terme du Secteur de l'Électricité Horizon 2030 (PDSE 2030). Rapport final volume 3 ETUDE DE L'OFFRE DE PRODUCTION.

[20] Système d'Information Energétique. Rapport annuel; 2008.

[21] Système d'Information Energétique. Rapport annuel; 2010.

[22] Wandji Le Cameroun et la question énergétique, l'Harmattan; 2007.

[23] Ministère de l'Environnement et des Forêts. Communication Nationale Initiale du Cameroun; 2004.

[24] Njomo Nkue et. Analyse du système énergétique camerounais dans une perspective de développement soutenable. Revue de l'Energie 2009;588:102-16.

[25] Renewable energy potential country report. Cameroon, Amsterdam; October 2006.

[26] Traitement de l'Information pour des Politiques Énergétiques favorisant l'Écodéveloppement (TIPEE). Cameroon; 2011.

[27] Laustsen J. Energy efficiency requirements in building codes, energy efficiency policies for new buildings. International Energy Agency; 2008. p. 85.

[28] Lighting Africa, 'Lighting Africa Policy Report Note - Cameroon'. IFC and WB; 2012.

[29] CA2D. Livre Blanc de l'Efficacité Energétique du Bâtiment tertiaire et collectif dans le 06, 1-127.

[30] Agence de l'Environnement et de la maitrise de l'Energie (ADEM); 2013.

[31] Kwong Qi Jie, Ali Yusoff. A review of energy efficiency potentials in tropical buildings - perspective of enclosed common areas. Renew Sustain Energy Rev 2011;15:4548-53.

[32] The energy efficiency strategy: the energy efficiency opportunity in the UK; November 2012

[33] Chirarattananon S, Taweekun J. A technical review of energy conservation programs for commercial and government buildings in Thailand. Energy Convers Manag 2003;44(5):743-62. 
[34] Lam JC, Chan RYC, Tsang CL, Li DHW. Electricity use characteristics of purpose built office buildings in subtropical climates. Energy Convers Manag 2004;45 (6):829-44.

[35] Li DHW, Wong SL, Lam JC. Climatic effects on cooling load determination in subtropical regions. Energy Convers Manag 2003;44(11):1831-43.

[36] Brounen D, Kok N, Quigley JM. Residential energy use and conservation: economics and demographics. Eur Econ Rev 2012;56:931-45.

[37] Li DHW, Yang L, Lam JC. Impact of climate change on energy use in the built environment in different climate zones-a review. Energy 2012;42:103-12.

[38] De Wilde P, Tian W. Towards probabilistic performance metrics for climate change impact studies. Energy Build 2011;43:3013-8.

[39] Roshan GR, Orosa J, Nasrabadi T. Simulation of climate change impact on energy consumption in buildings, case study of Iran. Energy Policy 2012;49:731-9.

[40] Levinson Arik. California energy efficiency: lessons for the rest of the world, or not? J Econ Behav Organ 2014;107:269-89.

[41] Pan Wei, Garmston Helen. Building regulations in energy efficiency: compliance in England and Wales. Energy Policy 2012;45:594-605.

[42] Ambrose Dodoo, Leif Gustavsson. Roger Sathre. Building energy-efficiency standards in a life cycle primary energy perspective. Energy and Buildings 2011;43:1589-97.

[43] Evans Meredydd, Yu Sha, Song Bo, Deng Qinqin, Liu Jing, Delgado Alison. Building energy efficiency in rural China. Energy Policy 2014;64:243-51.

[44] Iwaro Joseph, Mwasha Abraham. A review of building energy regulation and policy for energy conservation in developing countries. Energy Policy 2010;38:7744-55.

[45] Motawa Ibrahim, Oladokun Michael. A model for the complexity of household energy consumption. Energy Build 2015;87:313-23.

[46] Groesser Stefan N. Co-evolution of legal and voluntary standards: development of energy efficiency in Swiss residential building codes. Technol Forecast Soc Chang 2014;87:1-16.

[47] Heier Johan, Bales Chris, Martin Viktoria. Combining thermal energy storage with buildings - a review. Renew Sustain Energy Rev 2015;42:1305-25.

[48] Pantong K, Chirarattananon S, Chaiwiwatworakul P. Development of energy conservation programs for commercial buildings based on assessed energy saving potentials. Energy Procedia 2011;30:70-83.

[49] Li Jun, Colombier Michel, Giraud Pierre-Noel. Decision on optimal building energy efficiency standard in China - the case for Tianjin. Energy Policy 2009;37:2546-59.

[50] Salvalai Graziano, Masera Gabriele, Sesana Marta Maria. Italian local codes for energy efficiency of buildings: theoretical definition and experimental application to a residential case study. Renew Sustain Energy Rev 2015;42: 1245-1259.

[51] Assaf Sameer, Nour Mutasim. Potential of energy and water efficiency improvement in Abu Dhabi's building sector-analysis of estidama pearl rating system. Renew Energy 2014:1-8.

[52] Zhou Lu, Li Jing, Hung Chiang Yat. Promoting energy efficient building in China through clean development mechanism. Energy Policy 2013;57:338-46.

[53] Bagheri Farshid, Mokarizadeh Vahab, Jabbar Mohsen. Developing energy performance label for office buildings in Iran. Energy Build 2013;61:116-24.

[54] National energy efficiency policy. Strategy and action plan in the electricity sector in Cameroon. Final report - Draft Mars 2014, p. 9-76.

[55] Etude de la consommation et de la conservation d'énergie électrique dans le secteur public. Rapport final - Econoler International; Décembre 2003.
[56] PDSE 2030 - Power Sector Development Master Plan - IDC/EDF/SOGREAH/ BDS; 2006.

[57] Updating the development plan of the electricity sector by 2030. Study of the demand STUDI international; 2012.

[58] Study of consumption and conservation of electrical energy in public sector Final report; December 2003.

[59] Karekezi Stephen, Kithyoma Waeni. Renewable energy in Africa: prospects and limits. In: Proceedings of the workshop for African energy experts; 2-4 June 2003.

[60] Karekezi Stephen. Renewables in Africa - meeting the energy needs of the poor. Energy Policy 2002;30(11-12) Special issue - Africa: improving modern energy services for the poor. Oxford: Elsevier Science Limited.

[61] IEA (International Energy Agency). Energy statistics and balances of NonOECD countries. Paris: OECD/IEA; 2001.

[62] World Bank. African development indicators 2003. Washington DC: The World Bank; 1996.

[63] Karekezi Stephen, Kimani John. Status of power sector reform on the poor Energy Policy, 30; 2002 Special issue - Africa: improving modern energy services for the poor.

64] Karekezi S, Karottki R. A contribution to the Draft Paper on the role of new and renewable energy sources of energy from the perspective of environmental problems associated with current patterns of energy use and consumption. Foundation for Woodstove Dissemination/Danida Centre for Renewable Energy, Nairobi; 1989.

[65] Perez-Lombard L, Ortiz J, Pout. C. A review on buildings energy consumption information. Energy Build 2008:40:394-8.

[66] Karekezi S, Ranja T. Renewable energy technologies in Africa. Oxford, U.K: ZED Books and AFREPREN; 1997.

[67] Karekezi S, Turyareeba P. Renewable energy technologies: mini and micro hydro power in Eastern and Southern Africa. AFREPREN, Nairobi (Kenya). 2; 1995. p. 6-8.

[68] De Gouvello C, Dayo Felix, Thioye M, Banque Etude. Mondiale: Projets énergétiques Propres pour le Développement de l'Afrique Subsaharienne.

[69] AFREPEN. Liaison Energie-Francophonie, Les Energies renouvelables en Afrique, 〈http://www.afrepren.org/Renewables\%20Energy\%20in\%20Africa\%20-\% 20French.pdf $\rangle$.

[70] Mise en œuvre de l'agenda 21 par le cameroun. Rapport national du cameroun sur l'environnement et le developpement durable (rio + 10); Septembre 2001.

[71] Lee WL, Yik FWH. Regulatory and voluntary approaches for enhancing energy efficiency of buildings in Hong Kong. Appl Energy 2002;71:251-74.

[72] Lee WL, Yik FWH. Regulatory and voluntary approaches for enhancing building energy efficiency. Prog Energy Combust Sci 2004;30:477-99.

[73] ASHRAE. ASHRAE Standard 90.1-1989, American Society of Heating Refrigerating and Air-Conditioning Engineers. Atlanta; 1989.

[74] Building Regulations Part L1. Conservation of fuel and power in dwellings 2002 edition; Part L2, Conservation of fuel and power in buildings other than dwellings. Office of the Deputy Prime Minister, UK $\langle$ http://www.safety.odpm. gov.uk/bregs/brads.htm>.

[75] J'aime Madagascar. Electrification rurale en Marche; Septembre-Octobre 2006. No. 13, p. 8

[76] L'Express de Madagascar. Energie renouvelable, les outils d'installation exonérés. Vendredi 8Mai 2013. 